DOI https://doi.org/10.30525/978-9934-26-073-5-2-22

\title{
ЕМОТИВНА ФУНКЦІЯ ЗВЕРТАННЯ: УКРАЇНСЬКО-НІМЕЦЬКІ ПАРАЛЕЛІ (НА МАТЕРІАЛІ НІМЕЦЬКИХ ТА УКРАЇНСЬКИХ ТЕЛЕНОВЕЛ)
}

\author{
Меньшикова О. С. \\ аспірант кафедри германських та східних мов \\ Міжнародного гуманітарного університету \\ м. Одеса, Україна
}

Сьогодні в контексті антропоцентричної парадигми звертання досліджується не тільки як структурний елемент речення 3 певним набором функцій, а і як соціокультурний та етнокультурний компонент $[1 ; 3 ; 4 ; 5 ; 6 ; 7]$. Хоча в науковій літературі звертання віднесено до вагомих мовних універсалій, та в кожній лінгвокультурі форма звертання в рамках мовленнєвого етикету реалізуються по-різному і має специфічні структурні, семантичні та етнічні особливості [1, с. 3]. Вибір іменних та займенникових форм звертання зумовлюють також такі чинники як соціальний статус, рівень освіти, вікові та гендерні особливості комунікантів, важливу роль відіграють настрій та емоційний стан співбесідників [6, с. 73-75].

Мета нашого дослідження: з'ясувати специфіку вживання різних іменних форм звертання в українських та німецьких теленовелах для ілюстрації позитивних та негативних емоцій на екрані. Для досягнення поставленої мети треба розв'язати наступні завдання: 1) виокремити 3 потоку позитивних та негативних емотивних висловлювань іменні звертання; 2) класифікувати зафіксовані звертання за семантичними та структурними ознаками; 3) порівняти співвідношення та частотність різних типів звертання на матеріалі позитивних та негативних емотивних висловлювань; 4) провести паралелі в обох досліджуваних мовах.

Матеріалом для дослідження стали звертання 3 масиву речень оригінальних німецьких: «Sturm der Liebe», «Alisa - folge deinem Herzen» та укракїнських «Тільки кохання», «Дві матері» теленовел (8000 речень, біля 60000 слів). Кількість звертань на матеріалі української мови виявилася значно вищою, так само як і словотвірна та синонімічна варіативність. 
На матеріалі обох мов звертання в висловлюваннях на позначення негативних та позитивних емоцій були поділені на 3 групи (див. рис (1), (2)).

\section{1. Антропоніми;}

2. Родинні номінації (відповідно до функції в родині);

3. Пестливі, іронічні, емоційні номінації.

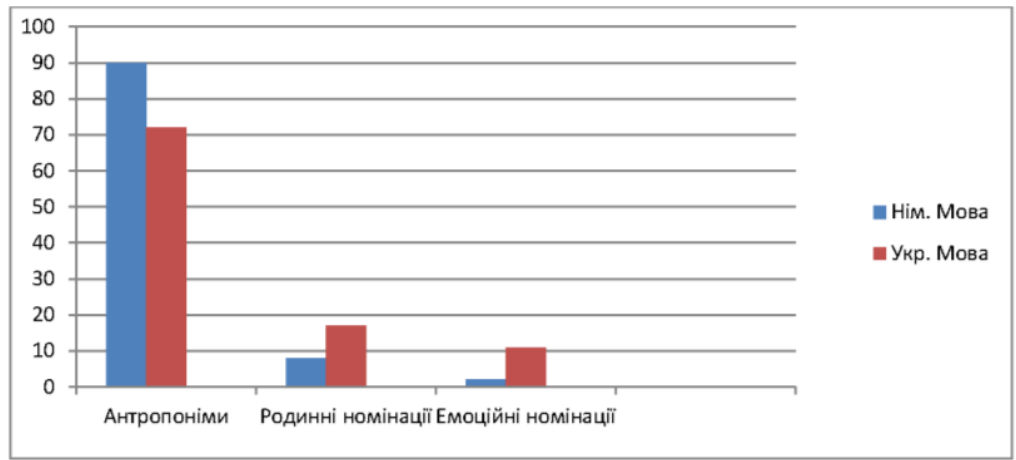

Рисунок 1. Типологізація звертань в висловлюваннях з негативними емоціями на матеріалі української та німецької мов у відсотках.

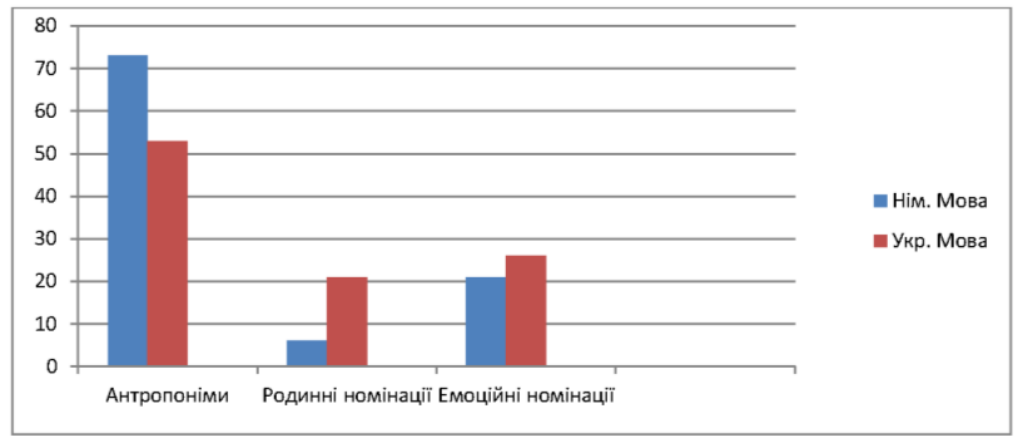

Рисунок 2. Типологізація звертань в висловлюваннях з позитивними емоціями на матеріалі української та німецької мов у відсотках.

3 наведених діаграм можна зробити висновок, що в моделюванні звертань персонажних реплік у німецьких та українських теленовелах наявні деякі розбіжності, так само як наявні розбіжності в моделюванні позитивних та негативних емоцій. 
В обох досліджуваних мовах найбільш продуктивною моделлю виявились звертання-анатропоніми в препозиції до речення. Звертання німецькою мовою $є$ майже стовідсотково антропонімами, які вживаються без будь-якої додаткової суфіксації: Lars, Adrian, Tina. В українській мові спостерігається висока варіативність форм імені: Сергій, Сергійко, Сергійчику; Алю, Альбіно, Альбіночко, Алюню.

Родинні номінації виявилися більш типовими в україномовному масиві тексту. На матеріалі німецької мови були зафіксовані тільки частотні звернення до матері в 3 варіантах: Maта (мама), Mutti (матуся), Mutter (матір) словоформи та поодинокі номінації батька Рара (тато), Vater (батько). На матеріалі української мови визначені різні родинні функції в ролі звертання, 3 різними продуктивними словотвірними моделями суфіксації: тато, татусю, таточко, мамо, мамочко, матінко, доню, донечко, сину, синку, синочку, сестро, сестричко, брате, братику, тьотю, дідусю, бабусю.

Пестливі, іронічні та емоційні номінації в обох мовах більш частотні у матеріалі позитивних емотивних висловлювань. В українських теленовелах зазначено більш широкий синонімічний спектр, частотними прикладами виявилися: кохана/ коханий, красуня, білочко, розумниия, помічниця, сонще, сонечко, киџю, дорогенький, маленька моя, люба. В німецьких теленовелах частоними виявились тільки звернення Schatz (дорогий), Liebling (коханий, любий), в ролі нечастотних прикладів зафіксовані Engel (янгол), Späzchen (горобчику), Amore (любов моя), Mäuschen (мишеня), Streber (ботан), Mistkerl (падлюка), Idiot (idiom).

За умов універсальності морфологічних засобів парадигмам форм звертання в кожній мові наявні свої структурні особливості [1, с. 3]. В українській морфологічній системі для реалізації функції звертання існує особлива форма кличного відмінку. В сучасній німецькій мові такої форми іменника не має, а ії функції виконує називний відмінок [2, с. 68]. Відмінність форм називного та кличного відмінків в українській мові надає останньому певної виразності, у німецькій ж мові номінатив звучить стилістично нейтральніше [2, с. 70]. Емотивний ефект більш нейтрального німецького найменування за необхідністю підсилюється імпліцитно через додавання інтенсифікаторів. Крім того серед антропонімічних розбіжностей української та німецької мов слід зазначити наявність імен по батькові в українській мові, що в німецькій мові нівелюється етикетними шаблонами звертання.

У фактичному матеріалі теленовел обох мов не були зафіксовані поширені звертання, продуктивними структурними моделями стали: 
непоширене звертання, модель звертання + інтенсифікатор та звертання + займенник «мій».

На матеріалі української мови в емотивних висловлюваннях теленовел зафіксовано значно вищу щільність звертань, так само як вищу словотвірну і синонімічну варіативність. Крім того, в українській мові значно більше уваги приділяється родинним зв'язкам, які підкреслюються через звернення 3 номінацією усіх членів родини. В німецькій мові можна простежити такий зв'язок тільки до матері. Пестливі, та емотивні звернення в українській мові наявні як в реченнях з позитивною, так і у реченнях 3 негативною емотивністю, тоді як в німецькій мові даний тип звернень в реченнях з негативною емотивністю нечастотний. Найбільш ефективний тип звертання в обох мовах антропонімічні варіанти 3 можливим додаванням інтенсифікаторів.

\section{Література:}

1. Величко Н.М. Засоби звертання в німецькій мові другої половини XX - початку XXI століття: соціолінгвістичний аспект: дис. ... канд. філ. наук: 10.02.04. Київ, 2017. 260 с.

2. Жлуктенко Ю.О. Німецько-українські мовні паралелі (порівняльно-типологічна граматика). Київ: Вища школа, 1977. 263 с.

3. Чабаненко В.А. Стилістика експресивних засобів української мови. Запоріжжя: ЗДУ, 2002. 351 с.

4. Шаховский, В.И. Лингвистическая теория эмоций М.: Гнозис, 2008. 416 c.

5. Die Stellung der deutschen Sprache in der Welt. Berlin/München/ Boston: de Gruyter. 2015. 1295 S.

6. Ammon U. Zur sozialen Funktion der pronominalen Anrede im Deutschen. Zeitschrift für Literaturwissenschaft und Linguistik. 1972. 2 (7). S. 73-88.

7. Susanne Günthner. Praktiken erhöhter Dialogizität: onymische Anredeformen als Gesten personifizierter Zuwendung. Zeitschrift für germanistische Linguistik. 2016. № 44(3). S. 406-436. 